\title{
ЭТАПЫ СТАНОВЛЕНИЯ ЭКОНОМИЧЕСКОГО ОБРАЗОВАНИЯ В ШКОЛАХ РОССИЙСКОЙ ФЕДЕРАЦИИ
}

\section{STAGES IN THE FORMATION OF ECONOMIC EDUCATION IN SCHOOLS OF THE RUSSIAN FEDERATION}

\section{E. Kudashova}

Summary: Economic education today is in search of a new approach that is shaped by the experience of previous generations. Today, the interest of educated people in economic theory is increasing. This is due to the global changes that are taking place all over the world. Almost everyone is dealing with economic issues and problems. Most interactions in society are guided and coordinated by certain rules of the game. In economic behavior, property rights form a large and important part of the rules.

Keywords: economics, education, economic education, student.

\author{
Кудашова Елена Андреевна \\ Аспирант, ФГБОУ «Набережночелнинский \\ государственный педагогический университет», \\ 2. Набережные Челны \\ Elenazka_98@mail.ru
}

Аннотация: Экономическое образование сегодня находится в поиске нового подхода, который формируется с учетом опыта, накопленного предыдущими поколениями. Сегодня интерес образованных людей к экономической теории все более возрастает. Объясняется это теми глобальными переменами, которые происходят во всем мире. С экономическими вопросами и проблемами соприкасаются практически все. Большинство взаимодействий в обществе направляется и координируется определенными правилами игры. В экономическом поведении обширную и важную часть правил образуют права собственности.

Ключевые слова: экономика, образование, экономическое образование, ученик.

Школьное образование - ключевой компонент образовательной системы на данный момент в обществе, создающий у детей основные навыки и знания. На основании этого можно сказать, что школьное экономическое образование - это упорядоченный процесс, способствующий выработке практических и научных экономических знаний и умений. В современном мире школьное экономическое образование является комплексным, многоуровневым циклом. В его развитии можно подчеркнуть два этапа. Первый советский этап относится к периоду социализма, второй современный относится к рыночному типу хозяйствования.

Сегодня к рыночному типу относится экономика России, что определяет развитие экономической грамотности, культуры, мышления, данный фундамент выстраивается со школьной скамьи. Ключевой функцией экономического образования является создание у школьников ценностных ориентиров и установок, основанных на экономических знаниях. Навыкообразующая функция экономического образования является неотъемлемой частью экономической грамотности школьников. Ее важность обуславливается необходимостью участия подростков в разнообразных экономических ситуациях, возможностью защиты свои права и интересов. Как же должно развиваться экономическое образование в России? Для этого нужно обратиться к отечественному историко-педагогическому опыту его становления в стране. Предысторией процесса становления отечественной школы экономического образования является период с девятнадцатого века по начало двадцатого века. Период до 1861 г. считается дорефор- 
менным, он основан на практике профессионализации народной школы того периода. После реформенный период до революции 1917 г. Этот период характеризуется ремесленным ученичеством, мануфактурным обучением, при фабриках и заводах были открыты школы. По 1930г. - революционно-реформистский период. Единая политехническая школа - развитие некоторых экономических знаний и умений, формирование гражданского и трудового самоопределения. С 1930 до начала 50-х годов XX века содержание экономического образования включало некоторые элементы экономических знаний о системе социалистического производства, изучение основных принципов современного производства, знания отдельных производственно-технологических процессов. Образование содействовало развитию практических умений применения знаний экономики в жизни, сохранению капитала. Так же формировались навыки сознательной дисциплины. С середины 1950 до конца 1960 годов, вопрос о необходимости получения учащимися экономических знаний, о развитии у них экономического мышления не ставился. Период с середины 1980-х до начала 1990-х годов можно назвать модернизационнореформистским этапом развития школьного экономического образования. Период начала 1990-х годов является началом образовательных реформ, в ходе которых решался ряд концептуальных вопросов: Уничтожением старой тоталитарной, административно-командной системы образования; Смена типа и характера экономической политики. Период с 2000 годов до сегодняшних дней выступает в качестве объекта периодизации, поскольку отражает процесс последовательного превращения теории и практики школьного экономического образования в Российской Федерации в целостную педагогическую систему. В составе экономического образования особое внимание уделяется вопросам организации труда, повышения производительности труда, прибыли, заработной платы.

В современной России необходимо отметить 3 направления процесса сущности экономического образования в школе: компетентность всех общеобразовательных дисциплин; внедрение специальных курсов по экономическим направлениям; специальная предпрофессиональная и профессиональная подготовка в школах. Экономические отношения нуждается в постоянном внимании к проблематике школьного экономического образования и построению у школьников верного представления о сущности экономических явлений и процессов. В экономическом образовании важную ступень занимают общеобразовательные школы. В педагогике есть законы, которые формируют условия для развития экономического образования молодежи. К таким условиям относятся настоящие концепции о закономерностях экономического развития, мышления, экономического сознания. Экономическое образование набирает обороты посредством переплетения дисциплин. До 1999 года в России при разработке программ и учебных планов по экономическому образованию школьников доминировал региональный аспект. Класс, с которого начиналось преподавание экономики, определялся, как правило, образовательным учреждением. В 2006 году в школах появилось профильное обучение, тем самым это позволило открывать социально-экономические классы. Значение экономического образования в России объясняется переходом экономики страны на рыночный тип отношений.

\section{ЛИТЕРАТУРА}

1. Аменд, А.Ф. Состояние и развитие теории и практики экономического воспитания школьников: Методические рекомендации/А.Ф. Аменд. - Челябинск: ЧГПИ, 1988. - 72с.

2. Аменд А.Ф. Тюнин, А.И. Непрерывное экономическое образование в условиях общеобразовательной школы [Текст]: Монография / А.И. Тюнин. - Алматы, 2004. -45 c.

3. Боровитина, Н.М. Значение экономического образования школьников для формирования экономической культуры общества [Текст] / Н.М. Боровитина.: Молодой ученый, 2011. —№10. Т.1. — С. 119-121.

4. Евплова, Е.В. Методика преподавания профессионально-экономических дисциплин [Текст] / Е.В. Евплова, Е.В. Гнатышина // учебно-методическое пособие. - Челябинск: Издательство ГБОУ СП0, 2015. - 108 с.

5. Ильин Г.Л. Философия образования: (идея непрерывности). М.: Вузовская книга, 2002. 223 с.

6. Кузнецова, Н.И. Изучение экономики как способ социализации личности. Ценности образования - образование как ценность [Текст] //. - Н.И. Кузнецова, М.М. Мавлюшов //. - Москва - Чебоксары: Межвузовский сборник научных трудов, 2007. - С. 55-60.

7. Любимов, Л.Л. Концепция структуры, содержания и организации экономического образования в полной средней школе [Текст] / Л.Л. Любимов, 2002. C. 14-28.

8. Маликов, Р.Ш. Экономическое образование в XXI веке / Р.Ш. Маликов, Е.А. Кудашова. — Текст: непосредственный // Молодой ученый. — 2019. — № 39 (277). - C. 246-248.

9. Орлова, Е.М. Экономическое образование: этапы, проблемы, перспективы / Сборник нормативно-методических материалов по проблемам экономики образования [Текст] / Е.М. Орлова. - М.: АПК и ПРО, 2002. 70.

10. Райзберг Б.А., Лозовский Л.Ш., Стародубцева Е.Б. Современный экономический словарь. — М.: ИНФРА-М. 
11. Сыроваткина Т.Н. / Основы экономики образования / Оренбург - 2013 год, 160 стр., 12 иллюстраций - электронный учебник.

12. Сабуров, Х.М., «Влияние основных тенденций развития современного образования на формирование личности учащихся»/выпуск журнала № 3 (часть 3) $з$ а 2014 год.

13. Тюнин, А.И. Непрерывное экономическое образование основа подготовки, экономически грамотного гражданина в условиях рыночной экономики В сборнике: Методика профессионального образования: от теории к практике. Сборник статей по итогам Всероссийской олимпиады по методике профессионального обучения/ А.И. Тюнин. - Челябинск, 2016. - С. 99-104.

○ Кудашова Елена Андреевна (Elenazka_98@mail.ru).

Журнал «Современная наука: актуальные проблемы теории и практики»

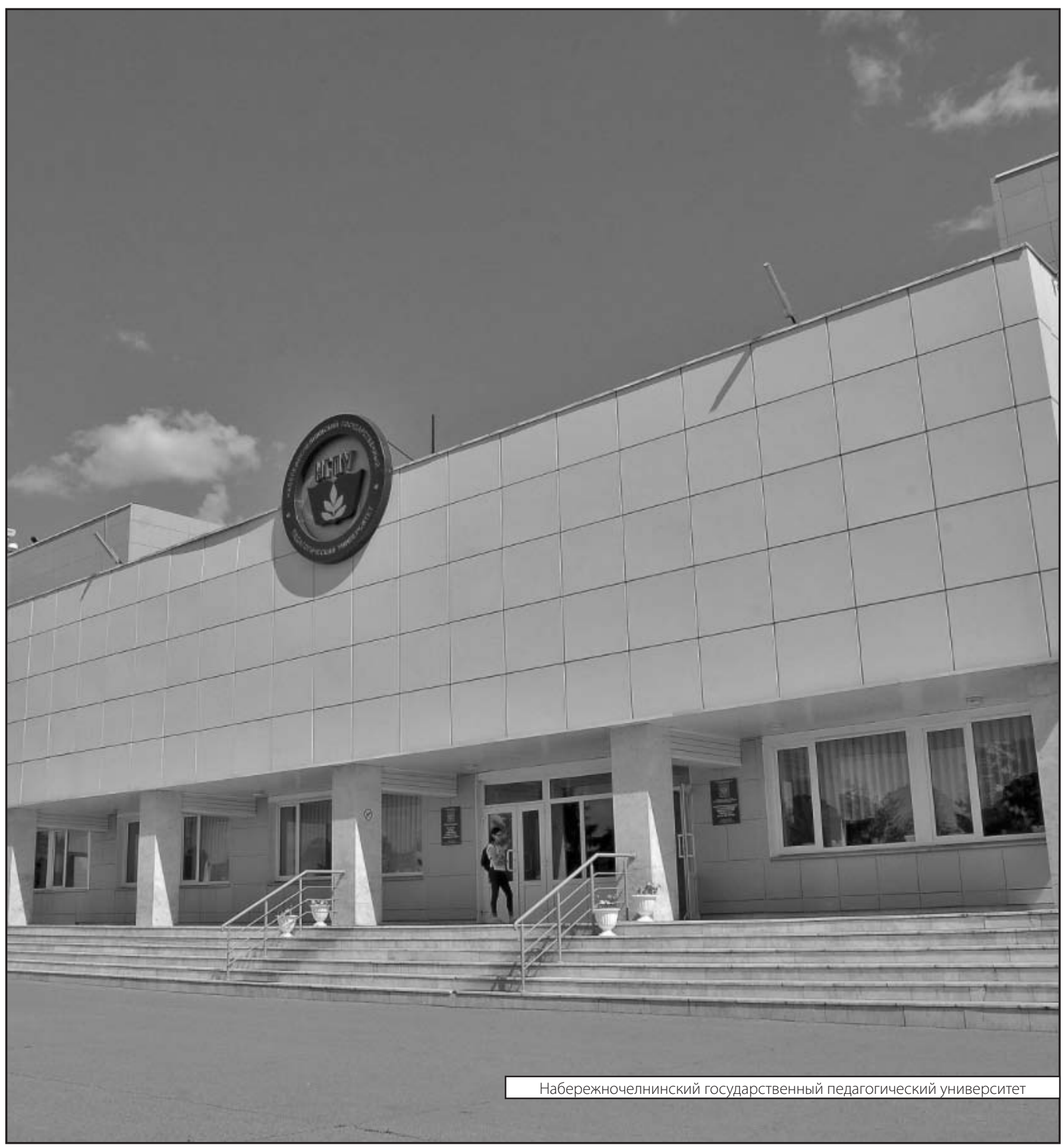

